Cornell Law Library

Scholarship@Cornell Law: A Digital Repository

Cornell Law Faculty Publications

Faculty Scholarship

1996

\title{
The United Nations Convention on Contracts for the International Sale of Goods: Guide to Research and Literature
}

Claire M. Germain

CornellLaw School,cmg13@cornell.edu

Follow this and additional works at: http://scholarship.law.cornell.edu/facpub

Part of the International Trade Commons, and the Legal Writing and Research Commons

\section{Recommended Citation}

Germain, Claire M., "The United Nations Convention on Contracts for the International Sale of Goods: Guide to Research and Literature" (1996). Cornell Law Faculty Publications. Paper 1059.

http://scholarship.law.cornell.edu/facpub/1059

This Article is brought to you for free and open access by the Faculty Scholarship at Scholarship@Cornell Law: A Digital Repository. It has been accepted for inclusion in Cornell Law Faculty Publications by an authorized administrator of Scholarship@Cornell Law: A Digital Repository. For more information, please contact jmp8@cornell.edu. 


\title{
The United Nations Convention on Contracts for the International Sale of Goods: Guide to Research and Literature
}

\author{
Claire M. Germain*
}

\section{INTRODUCTION}

On January 1, 1988, the United Nations Convention on Contracts for the International Sale of Goods ${ }^{1}$ (the Convention) became effective in the United States. In general, the Convention (also referred to as the "Vienna Sales Convention," the "Sales Convention," the "CISG," or the "UN Convention") applies to contracts for the sale of goods between enterprises having their places of business in different countries, provided these countries have adopted the Convention. Freedom of contract, however, is a fundamental principle of the Convention, and the parties may opt out or modify the effects of its provisions.

A Contracting State now has two sales laws: a domestic sales law and the Convention. In the United States, for example, the Uniform Commercial Code (UCC) and the Convention are now both US law. Attorneys with clients engaged in international trade should review their clients' procedures and forms in light of this new international sales law. ${ }^{2}$ Additionally, importers and exporters must determine whether or not the Convention applies to their transactions and whether or not they should exclude its application. ${ }^{3}$

* Edward Cornell Law Librarian and Professor of Law, Cornell Law School, Ithaca, NY, USA.

As this article is intended to be a guide for practitioners, bluebook form was altered in some instances so as to provide as much information as possible. Also published in 1 Review of the Convention on Contracts for the International Sale of Goods (CISG) 1995 117-145 (1996), edited by Cornell International Law Journal.

1 United Nations Convention on Contracts for the International Sale of Goods, U.N. Doc. A/CONF.97/18, art. 5 (1981) (opened for signature Apr. 11, 1980) [hereinafter CISG].

${ }^{2}$ See Peter Winship, Update: The New Legal Regime for International Sales Contracts, 2 REV. INT'L BuS. L. 107, 107-08 (1988).

${ }^{3}$ Id. at 111 . 
The Convention simplifies contract negotiation and dispute resolution. With the exception of up to five possible reservations, the Convention is a uniform text governing international sales transactions. It applies to contracts for the sale of goods between parties whose places of business are in different states when the states are Contracting States or when the rules of private international law, i.e., choice of law rules, lead to the application of a Contracting State's law. ${ }^{4}$

The Convention will govern a contract for the sale of goods between a US enterprise and an Italian enterprise because both the United States and Italy are Contracting States. In a contract between a US enterprise and a UK (which is not a Contracting State) enterprise, the Convention could apply by virtue of its Article 1(1)(b) if the forum choice of law rule led to the application of US law. The Convention, however, does not apply because the United States has adopted a reservation excluding Article 1(1)(b). ${ }^{5}$

Not all contracts and contract-related issues are governed by the Convention. For example, sales to consumers, issues of validity, the effect of a sale on third-party claims, and claims for death or personal injury caused by defects in the goods sold are excluded. Likewise, a number of contracts that are ancillary to an international sales contract, e.g., carriage insurance, letters of credit, and dispute resolution are not governed by the Convention.

This article maps Convention research strategies and explores some research issues relating to the Convention and its interpretation. More specifically, it provides guidance on where to start, how to find the leading texts, commentaries and practitioners' guides, and where to find the texts of documents. Finally, this article describes some new Internet-based projects, examines where to find additional information, and examines how to keep "up-to-date" with this burgeoning area of international sales law.

\section{History OF THE CONVENTION AND RESEARCH ISSUES}

\section{A. HISTORY OF THE CONVENTION}

The initial efforts to develop a uniform law of international sales began in 1930 under the auspices of the International Institute for the

${ }^{4}$ CISG, supra note 1, art. 1(1).

${ }^{5}$ Winship, supra note 2 , at 112. 
Unification of Private Law (UNIDROIT) ${ }^{6}$ UNIDROIT submitted two draft conventions: the Convention Relating to a Uniform Law on the International Sale of Goods (ULISG or ULIS) ${ }^{7}$ and the Convention Relating to a Uniform Law on the Formation of Contracts for the International Sale of Goods (ULFC or ULF). ${ }^{8}$ Although both draft conventions were adopted at a 1964 Diplomatic Conference in the Hague, many states, including the United States, did not ratify them. Some of the criticisms expressed were that the provisions primarily reflected the legal traditions and economic realities of continental Western Europe. ${ }^{9}$

The United Nations Commission on International Trade Law (UNCITRAL) ${ }^{10}$ was then commissioned to study the two 1964 conventions.

6 The International Institute for the Unification of Private Law (UNIDROIT) is an independent intergovernmental organization, seated in Rome, consisting of fifty-six member states. Its offices and numbers are: UNIDROIT, Via Panisperna 28, 00184 Rome, Italy; Tel.: (39/6) 69941372; Fax: (39/6) 69941394. Established in 1926 under the auspices of the League of Nations, its purpose is to examine ways of harmonizing and co-ordinating the private law of States and groups of States.

${ }^{7}$ Conventions on International Sale of Goods and Formation of Contracts for International Sale of Goods, Convention Relating to a Uniform Law on the International Sale of Goods, opened for signature July 1, 1964, 3 I.L.M. 854, 855 [hereinafter ULIS].

${ }^{8}$ Conventions on International Sale of Goods and Formation of Contracts for International Sale of Goods, Convention Relating to a Uniform Law on the Formation of Contracts for the International Sale of Goods, opened for signature July 1, 1964, 3 I.L.M. 854, 864 [hereinafter ULF].

${ }^{9}$ United Nations Convention on Contracts for the International Sale of Goods: Note by the Secretariat, U.N. GAOR Comm. on Int'l Trade Law, 21st Sess., U.N. Doc. A/CN.9/307 (1988) [hereinafter Secretariat Note].

${ }^{10}$ The United Nations Commission on International Trade Law (UNCITRAL) was established by the General Assembly in 1966. In establishing the Commission, the General Assembly hoped to reduce obstacles to the flow of international trade. The Commission carried the general mandate to further the progressive harmonization of international trade among nations. The Secretariat of UNCITRAL is the International Trade Law Branch of the United Nations Office of Legal Affairs. It is located in Vienna. UNCITRAL Secretariat, P.O. Box 500, Vienna International Centre, A-1400 Vienna, Austria; Phone: (43-1) 21345/4060 or 4061; Fax: (43-1) 237485; Secretary: Gerold Herrmann. For more information, refer to Germain's Transnational Law Research: $A$ Guide for Attorneys, Ch. IV, UNITED NATIONS (1991- . Looseleaf); UNCITRAL also 
After eight years of study, UNCITRAL approved a revision of the two 1964 uniform laws at a 1980 Diplomatic Conference in Vienna. This approved revision was the United Nations Convention on Contracts for the International Sale of Goods.

The Convention, which came into force on January 1, 1988, was adopted by eleven States representing every geographical region and every major legal, social, and economic system. In addition to the United States, ${ }^{11}$ the eleven adopting States included: Argentina, China, Egypt, France, Hungary, Italy, Lesotho, Syria, Yugoslavia, and Zambia. In 1989, Austria, Finland, Mexico, Sweden, Australia, and Norway became Contracting States. Since that time, over forty countries have ratified the Convention, and more countries are currently considering ratification. ${ }^{12}$ Two countries which have notably not ratified the Convention are the United Kingdom ${ }^{13}$ and Japan.

\section{B. RESEARCH ISSUES}

The Convention is of great academic and practical interest. The source of academic interest is the Convention's relevance as a study in comparative law topics such as unification of law ${ }^{14}$ and harmonization of

has a web site and can be reached at: http://www.un.or.at/uncitral/

${ }^{11}$ The Convention was submitted to the U.S. Senate for its advice and consent to ratification on September 21, 1983. United Nations Convention on Contracts for the International Sale of Goods, Sept. 21, 1983, S. Treaty Doc. 98-9, 98th Cong., 1st Sess. (1983) [hereinafter President's Letter]. An analysis of the convention accompanies the President's letter. The Senate gave its advice and consent on October 9, 1986, and the Convention went into effect on January 1, 1988.

${ }^{12}$ For current status information call the United Nations Treaty Section in New York at (212) 9633918.

${ }^{13}$ See Robert G. Lee, The UN Convention on Contracts for the International Sale of Goods: OK for the U.K.? 1993 J. Bus. L. (1993); Barry Nicholas, The United Kingdom and the Vienna Sales Convention: Another Case of Splendid Isolation? Address Before the Centro di Studi e Richerche di Diritto Comparato e Straniero (March 1993), in SAGGI, ConfERENZE E SEMINARI, 1993, at 1 .

${ }^{14}$ See, e.g., INTERNATIONAL ECONOMIC AND TRADE LAW--UNIVERSAL AND REGIONAL INTEGRATION (Olive M. Schmitthoff \& Kenneth R. Simmonds eds., Leyden: Sijthoff, 1976); EINHEITLICHES KAUFRECHT UND NATIONALES OBligationSRECHT (Peter Schlechtriem ed., Baden-Baden: Nomos, 1987). 
laws. ${ }^{15}$ The Convention has universal appeal because it was ratified by civil law and common law countries, developed and developing countries, and countries with different languages and cultures. Each country will produce a unique body of case law interpreting the Convention, and scholars from all over the world have already profusely commented on it. Finally, the Convention is of strong practical interest to practitioners because they use it in drafting and interpreting a variety of international contracts.

\section{RESEARCH METHODOLOGY}

The Convention has created a new area of substantive law directly applicable to a state's domestic legal system. In general, when researching transnational sales contract issues, researchers must consider both domestic sales law and international sales law (the Convention and other international trade usages and principles). Additionally, researchers must acquire some familiarity with any applicable foreign sales law and choice of law rules because the Convention does not deal with all international sales transactions. Furthermore, the Convention may not have entirely displaced the foreign or domestic law of the parties.

When researching the Convention, the following sources of law must be considered: (1) the text of the Convention; (2) its legislative history in the form of the 1980 Diplomatic Conference proceedings; (3) the Secretariat's official commentary on the 1978 Draft; (4) scholarly commentaries and writings; (5) cases decided worldwide; (6) international trade usages and practices (e.g., Article 9 of the Convention, UNIDROIT principles of international commercial contracts which might supplement the CISG when a CISG provision requires further interpretation); (7) lex mercatoria, the law used by merchants since the middle ages and created by standard commercial practices and arbitral decisions; ${ }^{16}$ and (8) previous UNIDROIT international sales conventions (i.e., ULIS or UFL). ${ }^{17}$

${ }^{15}$ See, e.g., Roy Goode, Reflections on the Harmonisation of Commercial Law, 1 UNIFORM L. REV. 54 (1991).

16 See Audit, infra part II.A.

${ }^{17}$ For instance, ULIS Article 82 and CISG article 74 on consequential damages and foreseeability are substantively identical, and the ULIS articles have generated commentaries and cases that may be useful in the interpretation of the CISG. 


\section{THE CISG LITERATURE: INFORMATION OVERLOAD?}

CISG literature is abundant. Numerous books have been published in many different languages: treatises and commentaries (in the German sense, meaning article-by-article commentaries on the Convention), practitioners' guides, colloquia proceedings, official governmental reports and studies, ${ }^{18}$ and doctoral and masters theses. Articles in international legal periodicals are even more prolific. Additionally, chapters of books which discuss the CISG are a part of much domestic literature. The CISG is also discussed in domestic sales law textbooks ${ }^{19}$ and casebooks, ${ }^{20}$ indicating that law schools are training a new generation of lawyers which will find dealing with the CISG "almost as natural and familiar as dealing with their own internal law." 21

In the past few years, many law review articles on the CISG have already been published in English alone. Many of the early articles commented solely on the Convention's text. However, now that over one hundred cases and arbitral awards have been rendered, several articles have commented on the cases and awards. In the United States, many articles in legal periodicals compare Convention provisions to UCC provisions. Several CISG symposium issues have been published (e.g., in the Northwestern Journal of International Law and Business and the Cornell International Law Journal). ${ }^{22}$ The 12th Congress of the International Academy of Comparative Law in Sydney/Melbourne included substantial discussion of the Convention.

${ }^{18}$ See, e.g., IRELAND LAW REFORM COMMISSION, REPORT ON UNITED NATIONS (VIENNA) CONVENTION ON CONTRACTS FOR THE SALE OF GOODS (Dublin: The Commission, 1980).

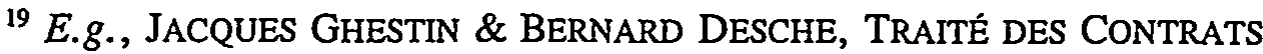
(Paris: L.G.D.J., 1990); 2 GEORGE RIBLOT \& RENE RIBLOT, TRAITÉ DE DROIT COMMERCIAL (13th ed., Paris: L.G.D.J., 1992).

${ }^{20}$ See, e.g., E. Allen FARNSWORTH ET AL., CASES AND MATERIALS ON COMMERCIAL LAW (5th ed. 1993); NICHOLAS, IMPRACTICABILITY AND IMPOSSIBILITY UNDER CISG (1984), reprinted in RALPH FOLSOM ET AL., INTERNATIONAL BUSINESS TRANSACTIONS: A PROBLEM-ORIENTED COURSEBOOK (3d ed. 1995).

${ }^{21}$ Peter Schlechtriem, Vienna Sales Convention 1980 (Recent Developments)--Developed Countries Perspectives, (Sept. 22, 1992) (unpublished manuscript on file with author).

${ }^{22}$ See infra part IV.A. 
The Congress's CISG topics have also been the object of several national reports. ${ }^{23}$

International lawyers, businesspersons, and exporters' practical interest in the Convention is reflected by articles on subjects which include the following: the impact of the Vienna Convention on drafting international sales contracts; risk of loss; comparison of the CISG, the UCC, and the British Sales of Goods Act; warranties in international sales under the CISG and the UCC; Convention provisions on the battle of the forms and warranties against infringement; and software license agreements under the CISG. Moreover, the domestic literature of various ratifying countries includes articles comparing the Convention's impact on particular legal systems. ${ }^{24}$

The seeming overabundance of CISG materials stems from the fact that in many countries the Convention is directly applicable to international sales contracts. As a result, the CISG is subject to intense scrutiny from scholars and practitioners alike (even though some lament the courts' lack of recognition of the Convention). In addition, because books on the topic sell well, publishers are eager to capitalize on CISG interest and support publishing efforts. Furthermore, the Convention's international character means that materials and commentaries are published in many different countries and in many different languages.

Because of the abundance of information, there is a need to sort out the most helpful publications and determine the types of materials needed. Publications come in a variety of formats-- print, disc, and increasingly in electronic form. These recent electronic projects represent breakthrough developments for legal researchers because they use new technologies (i.e., the Internet) and promote cooperation among scholars, practitioners, librarians, and computer specialists. Pace University School of Law is responsible for the major project in this regard. Largely due to the initiative

${ }^{23}$ See, e.g., Peter Schlechtriem, Unification of the Law for the

International Sale of Goods, in XII INTERNATIONALER KONGREß FÜR

RECHTSVERGLEICHUNG 1986 SYDNEY UND MELBOURNE/AUSTRALIEN 121 (1987);

K. Sutton, Methodology in Applying Uniform Law for International Sales (under the UN Convention), in LAW AND AustraliaN LEGAL THINKING IN THE 1980's 91 (Alice E.S. Tay ed., 1986).

${ }^{24}$ See, e.g., Christian Mouly, Que Change la Convention de Vienne sur la vente internationale par rapport au droit français interne?, 1991 RECUEIL DALLOZ SIREY 77. 
and vision of Albert Kritzer, who is leading the Pace Project, a new tool is being created that will bring together all CISG sources and scholars. Mr. Kritzer, working tirelessly and with experts worldwide, is devoted to making the CISG better known.

\section{WHERE TO START}

\section{A. Starting PoInTs}

The following are good places to start when researching CISG topics:

Audit, Bernard. The Vienna Sales Convention and the Lex Mercatoria, in LEX MERCATORIA AND ARBITRATION: A DISCUSSION OF THE NEW LAW MERCHANT 139 (Thomas Carbonneau ed., Dobbs-Ferry, N.Y.: Transnational Juris, 1990).

This book is an overview written by the University of Paris II's Professor Bernard Audit, a well-known French specialist on international commercial transactions.

Griffin, Joseph \& Michael Calabrese. New Rules for International Contracts, 74 A.B.A. J. 68 (1988).

This article provides the US practitioner a useful and concise summary of key CISG provisions.

Hancock, Stewart F., Jr. A Uniform Commercial Code for International Sales? We Have It Now, 67 N.Y. ST. B.J. 20 (Jan. 1995)

This piece contains a good overview and summary of the history, context, and importance of the Convention to US lawyers.

Lookofsky, Joseph. The 1980 United Nations Convention on Contracts for the International Sale of Goods in INTERNATIONAL ENCYCLOPEDIA OF LAWS-CONTRACTS 1-156 (Roger Blanpain ed., Kluwer Law \& Taxation, 1993).

Lookofsky, Joseph. Understanding the CISG in the USA: A Compact Guide to the 1980 United Nations Convention on Contracts for the International Sale of Goods (Kluwer Law International, 1995).

This book is a new, concise, introductory text for US law students and lawyers. 


\section{B. Commentaries and Major Texts}

\section{Commentaries and Major Texts in English}

Bianca, C.M. \& Michael Bonell. Commentary on the International Sales Law: The 1980 Vienna Sales Convention (Milan: Guiffre, 1987).

This book contains contributions from specialists from many different countries and includes a commentary on each article of the Convention. These commentaries consist of a provision's history, the meaning and purpose of the provision, and any problems arising in the provision's application. This book also includes the Convention's text in eight languages (the six official languages, plus German and Italian) and a bibliography.

Enderlein, Fritz \& Dietrich Maskow. International Sales Law: United Nations Convention on Contracts for the International Sale of Goods (New York: Oceana, 1992.)

This book provides an article-by-article commentary on the Convention and the Limitation Convention. It includes the text of the Convention and a bibliography.

Honnold, John. Uniform Law for International Sales under the 1980 United Nations Convention (2d ed., Boston: Kluwer, 1991.)

This work is cited by many commentators as the most useful and authoritative commentary. It reproduces the text of the 1980 Convention as well as the two 1964 conventions. The 1982 edition was translated into Spanish.

International Sales: The United Nations Convention on Contracts for the International Sale of Goods. (Nina M. Galston \& Hans Smit eds., New York: M. Bender, 1984.)

International Sale of Goods: Dubrovnik Lectures. (Peter Sarcevic \& Paul Volken eds., New York: Oceana, 1986).

Lookofsky, Joseph M. Consequential Damages in Comparative Context: From Breach of Promise to Monetary Remedy in the American, Scandinavian and International Law of Contracts and Sales (Copenhagen: Jurist og Okonomforbundets Forlag, 1989.)

Schlechtriem, Peter. Uniform Sales Law: The UN-Convention on Contracts for the International Sale of Goods (Vienna: Manz, 1986). This 
work is an article-by-article commentary on the Convention, written by a member of the then-West German delegation to the Conference.

2. Commentaries and Major Texts in Languages other than English

Actes du colloque sur la vente internationale. (Louis Perret et al. eds., Montreal: Wilson \& Lafleur, 1989).

Adame Goddard,J. El contrato de compraventa internacional (1994).

Audit, Bernard. La vente internationale de marchandises. Convention des Nations Unies du 11 avril 1980. (1990).

Béraudo, Jean Paul \& Philippe Kahn. La vente internationale de marchandises, CIIP, Marchés internationaux. (1989).

Das Einheitliche Wiener Kaufrecht. (Hans Hoyer \& Willibald Posch eds., Vienna: Orac, 1992).

Enderlein, Fritz, Dietrich Maskow \& Heinz Strohbach. Internationales Kaufrecht. (Berlin: Haufe, 1991).

Espina Otero, Alberto \& Alexandro Quintana Hurtado. Compraventa internacional de mercaderías. (Santiago de Chile: Editorial Juridica de Chile, 1985).

Ferrari, Franco. Vendita internazionale di beni mobili, I, Artt. 1-13 (1994).

Garro, Alejandro M. \& Alberto L. Zuppi. Compraventa internacional de mercaderías (Buenos Aires: La Rocca, 1990).

Gomard, Bernhard \& Hardy Rechnagel. International Kobelov (Copenhagen: Jurist og Okonomforbundet, 1990).

Guardiola Sacarrera, E. La compraventa internacional y los incoterms. (3d ed., Barcelona: Camara Official de Comercio, 1984).

Herber, Rolf \& Beate Czerwenka. Internationales Kaufrecht. Kommentar zu dem Übereinkommen der Vereinten Nationen (München: Beck, 1991). 
Herbots, Jacques H. Het transnationale koopverdrag. De Weense koopovereenkomst 1980 (Leuven: Acco, 1992).

Heuze, Vincent. La vente internationale de marchandises (Paris: GLN Joly, 1992).

Karollus, Martin. UN-Kaufrecht. Eine systematische Darstellung für Studium und Praxis (New York: Springer, 1991).

Lichtsteiner, R.A. Übereinkommen der Vereinten Nationen über Verträge über den internationalen Warenkauf (1989).

Loewe, Roland. Internationales Kaufrecht (1989).

Neumayer, Karl \& Catherine Ming. Convention de Vienne sur les contrats de vente internationale de marchandises. Commentaire. (Fr ançois Dessemontet ed., Lausanne: Centre du Droit de l'entreprise de l'Université de Lausanne, 1993).

Pelichet, Michel. La vente internationale de marchandises et le conflit de lois, 201 HAGUE ACADEMY OF INTERNATIONAL LAW 9-210 (1988).

Piltz, Bernhard. Internationales Kaufrecht: Das UN-Kaufrecht (Wiener Übereikommen von 1980) in praxisorientierter darstellung. (1993)

To be translated into English:

Reinhart, Gert. UN-Kaufrecht. (Heidelberg: Miler Juristischer Verlag, 1991).

Schlechtriem, Peter. Einheitliches UN-Kaufrecht. (1981).

Thiéffry, Jean \& Chantal Granier. La Vente Internationale (2d ed., Paris: Centre Français du Commerce Extérieur, 1992).

Kommentar zumEinheitlichen UN-Kaufrecht: das Übereinkommen der Vereinten Nationen über Verträge über den internationalen Warenkauf, CISG-Kommentar (Ernst Von Caemmerer \& Peter Schlechtriem eds., 2d ed., München: Beck, 1995).

This book will be translated into English in 1996. 
Wiener Kaufrecht (Eugen Bucher ed., Bern: Stämpfli, 1991).

Witz, Claude. Les premières applications jurisprudentielles du droit uniforme de la vente internationale (Paris: L.G.D.J., 1995).

\section{A. US PRACTITIONERS' GUIDES}

Kritzer, Albert H. Guide to Practical Applications of the UN Convention on Contracts for the International Sale of Goods (Boston: Kluwer Law \& Taxation, 1989).

Del Duca, Louis, Egon Guttman \& Alphonse Squilante. Sales under the Uniform Commercial Code and the Convention on International Sale of Goods (Cincinnati, Ohio: Anderson, 1993-).

Gabriel, Henry D. Practitioner's Guide to the Convention on Contracts for the International Sale of Goods (CISG) and the Uniform Commercial Code (UCC) (New York: Oceana, 1994).

This guide compares the substantive law of the Convention (CISG) with the UCC. It contains an appendix which cross-references UCC subjects with corresponding sections of the Convention.

Guide to the International Sale of Goods Convention (W. Hancock, ed., Chesterland, Ohio: Business Laws, 1987- ).

This looseleaf service contains text, comments, analysis and explanation with a bibliography.

U.N. Convention on Contracts for the International Sale of Goods: Annotated (Grant Ackerman ed., Boston: Warren, Gorham \& Lamont, 1992- ).

\section{RELATED BOOKS}

Bonell, Michael J. An International Restatement of Contract Law: The UNIDROIT Principles of International Commercial Contracts (Irvington, NY: Transnational Juris, 1994).

Commercial and Consumer Law: National and International Dimensions (Ross Cranston \& Roy Goode eds., (New York: Oxford University Press, 1993). 
Fox, William F. International Commercial Agreements: A Primer on Drafting, Negotiating, and Resolving Disputes (Boston: Kluwer Law \& Taxation, 1992).

Germain, Claire M. Germain's Transnational Law Research: A Guide for Attorneys, Ch. III and Ch. IV (Irvington, N.Y.: Transnational Juris, 1992).

International Uniform Law in Practice. (UNIDROIT ed., New York: Oceana; Rome: UNIDROIT, 1988).

International Commercial Agreements. (Practicing Law Institute ed., 1990).

International Trade for the Nonspecialist. (Paul H. Vishny ed., Philadelphia, PA: American Law Institute-American Bar Association, Committee for Continuing Professional Education, 1992).

Kouladis, Nicholas. Principles of Law Relating to Overseas Trade. (Cambridge, Mass.: Blackwell, 1994)

Kritzer, Albert H. International Contract Manual.

Negotiating and Structuring International Commercial Transactions: Legal Analysis with Sample Agreements. AGREEMENTS (Shelly P. Battram et al. eds., Chicago, Ill.: ABA, Section of International Law and Practice, 1991).

New Dimensions in International Trade Law: $A$ Canadian Perspective. (Jacob Ziegel \& William Graham eds., Toronto: Butterworths, 1982).

Principles of International Commercial Contracts. (UNIDROIT ed., Rome: UNIDROIT, 1994).

Schmitthoff, Clive M. Schmitthoff's Export Trade: The Law and Practice of International Trade (London: Stevens, 1990).

Transnational Law of International Commercial Transactions--Studies in Transnational Law. (Norbert Horn \& Clive Schmitthoff eds., Deventer: Kluwer Law International, 1982). 


\section{WHERE TO FIND TEXTS OF DOCUMENTS}

\section{A. TEXT IN UN AND US SOURCES}

\section{Text of 1980 Convention}

The text of the Convention is available to the practitioner through a variety of sources. ${ }^{25}$

\section{Text of 1964 Hague Conventions}

The texts of the conventions are available to the practitioner through a variety of sources. ${ }^{26}$

\section{UN Legislative History}

The official records of the 1980 Vienna diplomatic conference include the documents of the conference, the 1978 draft UNCITRAL text, a commentary on the draft text prepared by the UNCITRAL Secretariat, and the Secretary-General's analysis of comments and proposals on the 1978 draft made by governments and international organizations. ${ }^{27}$

Documents dealing with the pre-1980 work within UNCITRAL and its Working Group on the International Sale of Goods are reproduced in the

25 The official text of the Convention can be found in: United Nations Convention on Contracts for the International Sale of Goods, Apr. 10, 1980, U.N. Doc. A/CONF.97/18, Annex I, reprinted in 19 ILM 668 (1980). For US sources, the UN-certified Convention text is published in 52 Fed. Reg. 6262 (1987). It is also printed in the Appendix to Title 15 of the United States Code Annotated. 15 U.S.C.A. app. (West 1995). The text of the Convention is also to be found in Martindale-Hubbell Law Directory, International Law Digest volume (MARHUB;INTDIG, added to Lexis in August 1995).

${ }^{26}$ See ULIS, supra note 7; ULF, supra note 8.

27 The records of the 1980 Convention are officially published in United Nations Conference on Contracts for the International Sale of Goods-Official Records, UN Doc. A/CONF.97/19 (1981) [hereinafter Official Records]. These official records include the documents of the conference and summary records of the plenary meetings and of the meetings of the main committees. The principle conference documents are the 1978 draft UNCITRAL text, a commentary on this draft prepared by the UNCITRAL Secretariat, and the Secretary-General's analysis of comments and proposals on the 1978 draft made by governments and international organizations. 
UNCITRAL Yearbooks. ${ }^{28}$ Since these are not all in print and not well indexed, these documents have been collected, organized, and annotated by John Honnold.

\section{US Legislative History}

US legislative history materials can be found in many of the books mentioned under this section, the bibliographies, and the CIS index. ${ }^{29}$ These materials include: the introduction to the Senate, the Message of the President, Senate hearings, the Senate Committee Report, and the Senate consideration of the CISG.

US State Department documents include: Message From the President Containing the Legal Analysis of the United Nations Convention on Contracts for the International Sale of Goods ${ }^{30}$ and Report of the United States Delegation to the United Nations Conference on Contracts for the International Sale of Goods at Vienna, Austria. ${ }^{31}$

Pfund, Peter. International Unification of Private Law: A Report on United States Participation, 1985-86, 20 INT'L LAW. 623 (1986).

Liivak, Arno. International Sale of Goods: Documentary History of the 1980 U.N. Convention (Buffalo, New York: Hein, 1992).

${ }^{28}$ See, e.g., 1974 UNCITRAL Y.B. 44, U.N. Doc.

A/CN.9/SER.A/1974; 1977 UNCITRAL Y.B. 59, U.N. Doc. ACN.9/SER.A/1988.

${ }^{29}$ See Germain, supra note 25, Ch. III, § 13.16.16.

${ }^{30}$ Message from the President Containing the Legal Analysis of the United Nations Convention on Contracts for the International Sale of Goods, S. TREATY Doc. No. 98-9, 98th Cong., 1st Sess. (1983), reprinted in 22 I.L.M. 1368 (1984), and in Galston, supra note 33. See also Henry Landau, Background to U.S. Participation in United Nations Convention on Contracts for the International Sale of Goods, 18 INT'L LAW. 29 (1984).

${ }^{31}$ Report of the United States Delegation to the United Nations Conference on Contracts for the International Sale of Goods at Vienna, Austria, submitted to Secretary of State (1980) (Prepared by John O. Honnold, CoChairman of the Delegation) [hereinafter Delegation Report]. 


\section{B. BASIC MATERIALS AND LEgisLATIVE HiSTORY}

The Convention for the International Sale of Goods: A Handbook of Basic Materials ${ }^{32}$ is a useful compilation of documents which includes: an introduction and summary of the Convention, reproductions of several documents, a list of parties, signatories, and reservations, a message from the President, Department of State analysis, Senate Hearings, and the UNCITRAL Secretariat's Commentary on the 1978 Convention. This handbook also reprints Peter Winship's bibliography from International Lawyer $^{33}$ and includes texts in the five official UN languages.

The United Nations Conference on Contracts for the International Sale of Goods--Official Records: Documents of the Conference and Summary Records of the Plenary Meetings and of the Meetings of the Main Committees $^{34}$ is a UN document which contains the official proceedings of the 1980 Diplomatic Conference and materials on the history of the Convention. It also contains the official text of the Convention in Annex 1. Official records contained in this document include: the documents of the conference, the 1978 draft UNCITRAL text, ${ }^{35}$ a commentary on the draft text prepared by the UNCITRAL Secretariat, ${ }^{36}$ and the Secretary-General's analysis of comments and proposals made by governments and international organizations. ${ }^{37}$

John Honnold's Documentary History of the Uniform Law for International Sales ${ }^{38}$ includes 1980 Convention documents and pre-1980

32 The CONVENTION FOR the INTERNATIONAL SALE of GoOds: A HANDBOOK OF BASIC MATERIALS (D. Magraw \& R. Kathrein eds., 2d ed., Washington, D.C.: ABA Section of International Law and Practice, 1990).

${ }^{33}$ See Winship, Peter. The U.N. Sales Convention: A Bibliography of

English-Language Publications, 28 INT'L LAw. 401-23 (1994).

34 THE UNITED NATIONS CONFERENCE ON CONTRACTS FOR THE INTERNATIONAL SALE OF GOODS--OFFICIAL RECORDS: DOCUMENTS OF THE CONFERENCE AND SumMary RECORdS OF THE PlenaRy MEETINGS AND OF THE MEETINGS OF THE MAIN CoMmitTEES, 1981, U.N. Sales No. E.82.V.5 (1981).

${ }^{35}$ Delegation Report, supra note 32.

${ }^{36} \mathrm{Id}$.

37 Id.

38 JOHN HONNOLD, DOCUMENTARY HISTORY OF THE UNIFORM LAW FOR

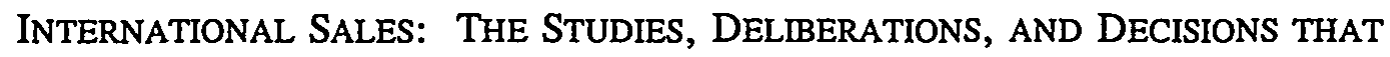
LED TO THE 1980 UNITED NATIONS CONVENTION WITH INTRODUCTIONS AND 
documents. Additionally, it covers the twelve-year legislative process for UNCITRAL (1969-1977) and the Vienna Diplomatic Conference (1980). Documents from nine volumes of the UNCITRAL Yearbook and the Official Records of the Vienna Conference are also reproduced. The book is organized and annotated with introductions, marginal references, tables, and a detailed index. John Honnold, who was in charge of the legal work for UNCITRAL and represented the United States at the 1980 Vienna Conference, is currently Professor Emeritus of Commercial Law at the University of Pennsylvania School of Law.

\section{JUdicial AND ARBITRAL DECISIONS INTERPRETING THE CISG}

A major question after ratification of any multilateral convention is whether there will be uniformity of interpretation. The Convention did not provide for a collection of decisions. UNCITRAL, however, is making relevant court decisions and arbitral awards available in an inexpensive format. ${ }^{39}$ UNCITRAL has asked states to designate national correspondents who will send court and arbitral decisions interpreting relevant Convention provisions (including abstracts of the texts) to the UNCITRAL Secretariat. The compiled abstracts are issued as a UN document several times a year. ${ }^{40}$

For example, Case Law on UNCITRAL Text: User Guide ${ }^{41}$ covers several UNCITRAL conventions and model laws and has a large section devoted to the Vienna Sales Convention. This sales document also contains a user guide and abstracts, written by national correspondents, for fifty-two cases and arbitral awards together with a list of the national correspondents and their addresses. These materials are now available over the Internet at:

EXPLANATIONS (Deventer: Kluwer Law \& Taxation, 1989).

${ }^{39}$ Dissemination of Decisions Concerning UNCITRAL Legal Texts and Uniform Interpretation of Such Texts: Note by Secretariat, U.N. GAOR, 40th Sess., U.N. Doc. A/CN.9/267 (1985).

${ }^{40}$ See Bernard Audit, The Vienna Sales Convention and the Lex

Mercatoria, in LEX MERCATORIA AND ARBITRATION: A DISCUSSION OF THE NEW LAND MERChANT (Thomans Carbonneau ed., Dobbs-Ferry, N.Y.: Transnational Juris, 1990), at 176.

${ }^{41}$ The CLOUT system is explained in UNITED NATIONS, COMMission ON INTERNATIONAL TRADE LAW, CASE LAW ON UNCITRAL TEXT (CLOUT): USER GUIDE, U.N. Doc. A/CN.9/SER.C/GUIDE/1 (1993) (available from the UNCITRAL Secretariat, P.O. Box 500, Vienna International Centre, A-1400, Vienna, Austria. Fax: 43-1-21345-5813). 


\section{http://www.un.or.at/uncitral}

Professor Michael Bonell and colleagues have gathered doctrinal references, cases and arbitral awards in the original language, with an English-language abstract in a software format. Unilex: A Comprehensive and "Intelligent" Data Base on the U.N. Convention on Contracts for the International Sale of Goods, On Disc is easy to use and the cross-references are very helpful. Published by Transnational Juris, it includes several updates a year.

Professor Michael Will of the University of Geneva has compiled decisions under the Convention in International Sales Law under CISG: The First Hundred Decisions. ${ }^{42}$ The decisions are arranged in chronological order by year and include information such as the countries involved; the subject of the litigation; the applicable Convention articles; cross-references to other sources where the case was reported; full-text of the cases; abstracts; and commentaries.

\section{INTERNET PROJECTS}

\section{Troms International Trade Law Project in Norway}

The Troms International Trade Law Project in Norway is led by Lecturer Ralph Amissah. The project's World Wide Web site is: http://ananse.irv.uit.no/trade_law/ It is an extensive site and well worth exploring since it expands constantly. The site contains an International Trade Law Materials section which includes the following subjects: International Trade Treaties, Conventions, Model Laws, Rules, and other relevant trade instruments organized by their date of formulation. Finally, the site includes information on International Organisations Related to Trade.

The site's CISG section includes the text of the Convention (1980) as well as a list of Contracting States and Status of the Convention. The section also reproduces the texts of other conventions and documents, such as the Convention on Agency in the International Sale of Goods, ${ }^{43}$ and the United

${ }^{42}$ Michael Will, InTERnational Sales LaW UNDER CiSG: THE FIRST HUNDRED DECISIONS (Geneve, Switzerland: M. Will, 1994).

${ }^{43}$ Convention on Agency in the International Sale of Goods, reprinted in 22 I.L.M. 249 (1983). 
Nations Convention on the Limitation Period in the International Sale of Goods with the amending Protocol of $1980 .{ }^{44}$

\section{Pace University Internet Project}

This large-scale project, named CISG W3, is funded by the National Center for Automated Information Research and sponsored by the Institute of International Commercial Law of the Pace University School of Law. It is directed by Professors Albert $\mathrm{H}$. Kritzer ${ }^{45}$ and Nicholas Triffin. ${ }^{46}$ The project's goal is to provide, through the Internet, the Convention's text, its legislative history, case law, and secondary Convention information sources. It is an important project that weaves together primary documents and commentaries with many hypertext cross-references.

The introductory segment of the project contains the text of each CISG article together with information related to the article and editorial comments. The information is organized as follows: Road map to the legislative history of the Article, Match-up of the Article with the $1978 \mathrm{draft}$ version, Secretariat Commentary of the draft version (the closest part to an Official Commentary on the Article), Match-up of the Article with Hague Conventions antecedents, Subject index on the Article with case law annotations, Selected bibliographic references to the Article (the underlined parts of which identify "links"), and Bibliographic references to books and law journal commentaries. So far, twenty-five leading US law journals and others from Scandinavia and Asia have granted licensing permission to the project.

44 U.N. Convention on the Limitation Period in the International Sale of Goods, June 14, 1974, U.N. Doc. A/CONF.63/15 (1974), reprinted in 13 I.L.M. 952 (1974), and Protocol Amending the Convention on the Limitation Period in the International Sale of Goods, Apr. 10, 1980, U.N. Doc. A/CONF.97/18, Annex II, reprinted in 19 I.L.M. 696 (1980). The 1974 Convention on the Limitation Period in the International Sale of Goods and its 1980 Protocol came into force for the United States on December 1, 1994. 33 I.L.M. 1619, 1620 (1994).

${ }^{45}$ Executive Secretary of the Pace Institute of International Commercial Law and Editor of the CISG project.

${ }^{46}$ Director of the Law Library and Director of the Pace Institute of International Commercial Law, and Internet Director of the Project. For further information: Pace University School of Law, 78 North Broadway, White Plains, N.Y. 10603, U.S.A. 
Finally, the "Editor's comments" section consists of cross-references to other related articles and materials. A powerful site search engine and a multi-lingual keyword descriptor thesaurus is being created, first in English, then in German.

\section{FOR MORE INFORMATION}

\section{A. ARTICLES}

Ferrari, Franco. Uniform Interpretation of the 1980 Uniform Sales Law, 24 J. INT'L \& CoMP. L.Q. 183 (1994).

Gabriel, Henri D. The Battle of the Forms: A Comparison of the United Nations Convention for the International Sale of Goods and the Uniform Commercial Code: The Common Law and the Uniform Commercial Code, 49 Bus. LAw. 1053-64 (1994).

Cornell International Law Journal, volume 21, pp. 419-589 (1988). This Symposium issue on the CISG contains seven interesting articles, including pieces written by John Honnold, Peter Winship, and Robert Hillman.

Dore, Isaak I. \& James E. Defranco, A Comparison of the Non-Substantive Provisions of the UNCITRAL Convention on the International Sale of Goods and the Uniform Commercial Code, 23 HARV. INT'L L.J. 49 (1982).

Eörsi, Gyula. A Propos the 1980 Vienna Convention on Contracts for the International Sale of Goods, 31 AM. J. CoMP. L. 333 (1983).

Feltham, J.D. The United Nations Convention on Contracts for the International Sale of Goods, J. Bus. L., Nov. 1981, at 346.

Honnold, John. Convention on the Limitation Period in the International Sale of Goods, 24 INT'L LAW. 583 (1990).

Journal of Law \& Commerce (Symposium issue) 8 J.L. \& COMM. (1988). 
Murphey, Arthur G., Jr. Consequential Damages in Contracts for the International Sale of Goods and the Legacy of Hadley, 23 GEO. WASH. J. INT'L L. \& ECON. 415 (1990).

Ndulo, Muna. The Vienna Sales Convention 1980 and the Hague Uniform Laws on International Sale of Goods 1964: A Comparative Analysis, 38 INT'L \& COMP. L.Q. 1-25 (1989). LAw. 3 (1984).

Symposium on International Sale of Goods Convention, 18 INT'L

Symposium Reflections on the International Unification of Sales Law, 8 Nw. J. INT'L L. \& BUS. 531 (1988).

Vergne, Francois. The "Battle of the Forms" Under the 1980 United Nations Convention on Contracts for the International Sale of Goods, 33 AM. J. CoMP. L. 233 (1985).

Winship, Peter. Energy Contracts and the United Nations Sales Convention, 25 TEX. INT'L L.J. 365 (1990).

Winship, Peter. Formation of International Sales Contracts under the 1980 Vienna Convention, 17 INT'L LAW. 1 (1983).

Winship, Peter. International Sales Contracts under the 1980 Vienna Convention, 17 U.C.C. L.J. 55 (1984).

\section{B. BIBLIOGRAPHIES}

The Pace Internet Project will include a comprehensive bibliography containing worldwide contributions. Additionally, the following bibliographies are also comprehensive and useful:

Honnold, John. Bibliography: International Sale of Goods, 27 AM. J. COMP. L. 345-49 (1979).

This bibliography contains materials on the 1964 uniform laws.

Jacobs, Daniel J. International Sale of Goods: $A$ Selective Bibliography, 44 REC. ASS'N BAR OF CITY OF N.Y. 342 (1989). 
UNCITRAL Yearbook. ${ }^{47}$ Each volume of the yearbook contains a bibliography of recent writings related to the work of UNCITRAL. This bibliography contains books and articles which are international in scope and in both English and foreign languages.

Will, Michael. International Bibliography on the Uniform Sales Law. (4th ed., Köln, Germany: Bundesstelle für Aussenhandelsinformation, forthcoming 1995).

Will, Michael. Internationale Bibliographie zum UN-Kaufrecht. (2d. ed., Saarbrucken: Europa-Institut der Universität des Saarländes, 1989).

Winship, Peter. A Bibliography of Commentaries on the United Nations International Sales Convention; Bibliography, 22 INT'L LAW. 605 (1988).

Winship, Peter. The U.N. Sales Convention: A Bibliography of English-Language Publications, 28 INT'L LAW. $401-23$ (1994).

C. Staying Up-To-Date

1. Books

To find additional books one should search library online catalogs by key-word or subject. The following Library of Congress subject headings may be useful: "Export sales contracts," and "United nations convention on contracts for the international sale of goods (1980)." Furthermore, major US and UK research libraries can now be accessed via the Internet allowing the researcher to browse through these libraries' catalogued collections.

\section{Articles}

There are several major indexes which can be used to find legal periodical articles which deal with the CISG. For articles in primarily English-language legal periodicals and Festschriften, the following monthly indexes may be useful:

${ }^{47}$ See, e.g., supra note 29. 
Legal Resource Index (CD-ROM, print version called Current Law Index.

Index to Legal Periodicals (Westlaw: ILP).

Index to Foreign Legal Periodicals (print; also on Westlaw: IFLP, and as an electronic subscription) for legal periodicals in languages other than English, and Festchriften.

The weekly Current Index to Legal Periodicals (also on Westlaw: cilp) is a good source for articles recently published. Finally, eclipse services on Lexis and Westlaw can be set up for weekly or daily updates. For current awareness, it is especially useful to browse through specialized periodicals.

\section{CONCLUSION}

The Convention has provided business people and lawyers with a simpler and more secure legal basis for international trade. Law professors, students, and practitioners will no doubt continue studying the CISG and its accompanying case law. In this context, it is important to underline the usefulness of the Pace University and other Internet projects in using new technologies to further the dissemination of legal information across borders. 